\title{
Did Wearing Mask and Lockdowns Affect Vitamin D Levels During the Coronavirus Disease-2019 Pandemic?
}

\author{
Koronavirüs Hastalığı-2019 Pandemisinde; Maske ve Sokağa Çıkma Yasağı Vitamin D \\ Seviyelerini Etkiledi Mi? \\ (iD Serap Satış, ID Alparslan Yetişgin \\ Harran University Faculty of Medicine, Department of Physical Medicine and Rehabilitation, Şanlıurfa, Turkey
}

\section{Abstract}

Objective: To investigate the effects of wearing mask and lockdowns during the coronavirus disease-2019 (COVID-19) pandemic on the vitamin D levels in females.

Materials and Methods: This retrospective study included female adults aged 18-64 years who underwent vitamin D evaluation at our hospital in April and May from 2017 to 2020. Vitamin D levels were categorized as follows: $<10 \mathrm{ng} / \mathrm{mL}$ (severe deficiency); 10 to $<20 \mathrm{ng} / \mathrm{mL}$ (deficiency); 20 to $30 \mathrm{ng} / \mathrm{mL}$ (insufficiency) and $>30 \mathrm{ng} / \mathrm{mL}$ (normal).

Results: A total of 835 (90.8\%) out of 920 females had vitamin D deficiency, and among them 463 (50.3\%) had vitamin D severe deficiency. In April and May of 2020 (during the national lockdown period), 74 (89.2\%) out of 83 subjects had vitamin D deficiency. Vitamin D levels were found to be higher in 2017 than the other years $(p<0.001)$. There was no significant difference between the lockdown year $(2020)$ and the 2018 and 2019 years regarding vitamin D levels ( $p>0.05$ ).

Conclusion: Our findings indicate that there is a serious and urgent public health problem regarding with vitamin D deficiency (>90\%) in our population; and about $50 \%$ of them had severe deficiency. This problem was not different during the lockdown period compared with the previous two years.

Keywords: Coronavirus 2019, lockdown, outbreak, mask, vitamin D deficiency

\section{Öz}

Amaç: Koronavirüs hastalığı-2019 (COVID-19) pandemisi sırasında maske takmanın ve sokağa çıkma yasağının kadınlarda D vitamini düzeyleri üzerindeki etkilerini araştırmaktır.

Gereç ve Yöntem: Bu retrospektif çalışmaya 2017-2020 yılları arasında Nisan ve Mayıs aylarında hastanemizde D vitamini değerlendirmesi yapılan 18-64 yaş arası erişkin kadınlar dahil edildi. D vitamini düzeyleri şu şekilde kategorize edildi: $<10 \mathrm{ng} / \mathrm{mL}$ (şiddetli eksiklik); 10 ile $<20$ $\mathrm{ng} / \mathrm{mL}$ arası (eksiklik); 20 ile $30 \mathrm{ng} / \mathrm{mL}$ arası (yetersizlik) ve $>30 \mathrm{ng} / \mathrm{mL}$ (normal).

Bulgular: Dokuz yüz yirmi kadından toplam $835^{\prime}$ inde $(\% 90,8)$ D vitamini eksikliği, 463'ünde $(\% 50,3)$ ciddi D vitamini eksikliği vardı. 2020 yııının Nisan ve Mayıs aylarında (ulusal karantina döneminde), 83 kişiden 74'ünde (\%89,2) D vitamini eksikliği vardı. 2017 yılında D vitamini düzeyleri diğer yıllara göre daha yüksek bulundu ( $p<0,001)$. D vitamini düzeyleri açısından karantina yılı (2020) ile 2018 ve 2019 yılları arasında anlamlı bir fark yoktu ( $p>0,05)$.

Sonuç: Bulgularımız toplumumuzda D vitamini eksikliği (>\%90) ile ilgili ciddi ve acil bir halk sağlı̆̆ı sorunu olduğunu göstermektedir; ve yaklaşık \%50'sinde ciddi eksiklik vardır. Bu sorun, karantina döneminde önceki iki yıla kıyasla farklı değildir.

Anahtar kelimeler: Koronavirüs 2019, karantina, sokağa çıkma yasağı, maske, vitamin D eksikliği

\section{Introduction}

Vitamin $D$ is one of the most important hormones in the body, contributing to bone mineralization by affecting the calcium and phosphorus metabolism $(1,2)$. Ultraviolet-B (UV$B$ ) rays constitute the main source of vitamin D. Under normal conditions, $90-95 \%$ of vitamin D in human skin is synthesized from 7-dehydrocholesterol following exposure to UV-B radiation from the sun and is then metabolized in the liver and kidney (3-5).

The 25-hydroxyvitamin D [25(OH)D] is the major circulating form of vitamin D with a half-life of 2-3 weeks. It is considered the best indicator of vitamin D supply to the body from nutritional intake

Address for Correspondence/Yazıșma Adresi: Serap Satış Ph.D., Harran University Faculty of Medicine, Department of Physical Medicine and Rehabilitation, Şanlıurfa, Turkey Phone: +90 5069765761 E-mail: mdseraps@gmail.com ORCID ID: orcid.org/0000-0002-5496-197X Received/Geliş Tarihi: 29.04.2021 Accepted/Kabul Tarihi: 23.06.2021 
and endogenous production (3). Although vitamin D reference ranges vary according to the laboratory and study method utilized, vitamin D status is often categorized as $<20 \mathrm{ng} / \mathrm{mL}$, deficient; $20-30 \mathrm{ng} / \mathrm{mL}$, insufficient; $30 \mathrm{ng} / \mathrm{mL}$, normal; 150-200 $\mathrm{ng} / \mathrm{mL}$ and hypervitaminosis (6). Studies conducted in Turkey have indicated significantly low vitamin D levels in subjects. Of note, a study conducted in Ankara province detected vitamin D deficiency in $51.8 \%$ and vitamin D insufficiency in $20.7 \%$ of the subjects (7). Vitamin D deficiency has been shown to be associated with numerous diseases particularly including bone, cardiovascular and respiratory system, autoimmune, diabetes mellitus, and neurodegenerative diseases, there is insufficient data regarding the control of these diseases with vitamin $D$ replacement (8-14).

Coronavirus disease-2019 (COVID-19) is an infectious disease that was first seen in Wuhan, Hubei Province, China in late 2019. Severe acute respiratory syndrome-coronavirus-2 (SARSCoV-2) is the strain of coronavirus causing COVID-19, spreading rapidly mostly via droplets and remaining a serious public health problem worldwide. World Health Organization identifies novel coronavirus as global pandemic on March 11, 2020 (15). Selfprotection is the most important measure in preventing SARSCoV-2. Therefore, wearing a facemask has become an official obligation and partial lockdowns have been imposed in Turkey as in the whole world. Due to these restrictions, vitamin D deficiency has become more prevalent mainly because individuals cannot leave home as easily as they did before and even when they leave, they need to cover their faces with a facemask. To our best knowledge, there is no study in the literature investigating this phenomenon (i.e. the effects of lockdowns) following COVID-19 outbreak.

In this study, we aimed to investigate the effect of limited sunshine exposure in COVID-19 pandemic (limited to months) on vitamin $D$ status.

\section{Materials and Methods}

The retrospective study included female adults aged 18-64 years who underwent vitamin D measurement in our hospital in April and May of the years from 2017 to 2020. Individuals aged 65 years and over were excluded from the study since they were not allowed to apply to healthcare centers except for emergency conditions throughout the lockdown periods. Serum vitamin D levels were assessed by using a Shimadzu HPLC system with the LC-MS/MS method $(16,17)$.

The study protocol was approved by the local Ethics Committee of Clinical Research of Harran University (decision no: HRU/20.11.14, date: 15.06.2020). The study was conducted in accordance with the principles of the Declaration of Helsinki.

The inclusion criterion was having complete medical records that involved at least one vitamin D measurement within the last one year. Exclusion criteria were as follows; history of vitamin D supplementation, osteoporosis therapy, or surgery within the last six months, liver or kidney failure that could affect the vitamin D synthesis, use, need, or metabolism of vitamin D, pregnancy, breastfeeding, use of glucocorticoid or antiepileptic drugs (including gabapentin and pregabalin), history of thyroid/ parathyroid surgery, malabsorption, malignancy, thyroid/ parathyroid disease requiring treatment, Paget's disease, genetic diseases that could disrupt bone metabolism and turnover, organ transplantation. Additionally, individuals that had a disability that prevented them from going out and a medical problem that caused them to remain immobile such as hemiplegia, paraplegia, fracture, and diabetic foot were also excluded from the study. In total, 921 patients fulfilled the inclusion criteria and were included in the study. Vitamin $D$ status was categorized as follows; $<10 \mathrm{ng} / \mathrm{mL}$ (severe deficiency); 10 to $<20 \mathrm{ng} / \mathrm{mL}$ (deficiency); $20-30 \mathrm{ng} / \mathrm{mL}$ (insufficiency); $>30 \mathrm{ng} / \mathrm{mL}$ (normal).

\section{Statistical Analysis}

Data were analyzed using SPSS for Windows version 20.0 (SPSS Inc., Chicago, IL, USA). Numerical variables are shown as median (minimum-maximum), categorical variables as $\mathrm{n}(\%)$. Normal distribution was tested by Kolmogorov-Smirnov test. Continuous variables were compared using Kruskal-Wallis test as they were not distributed normally. Categorical variables were compared using chi-square test. A p value $<0.05$ was considered significant.

\section{Results}

A total of 920 female adults [37 (18-64) years] were included (Table 1). A total of 835 females (90.8\%) had vitamin D deficiency i.e. $463(50.3 \%)$ as severe and $372(40.4 \%)$ as non-severe deficiency. When all participants were classified according to their age ranges, there was no significant difference in vitamin $D$ levels among the age groups ( $p>0.05)$.

Serum vitamin D levels of the subjects are given in Table 2 . Vitamin D levels were found to be higher in 2017 than the other years-both in April and May (both $p<0.001$ ). There was no significant difference among the lockdown year (2020) and 2018 or 2019 regarding vitamin D status ( $p>0.05)$. In April and May of 2020 (in the national lockdown period), 74 (89.2\%) out of 83 subjects had vitamin D deficiency (Table 3). The frequency of vitamin D deficiency was lowest in 2017-both in April (51.9\%) and May (83\%) (Both p<0.001). 807 (96.4\%) out of 837 female patients had vitamin $D$ deficiency in the last three years.

\section{Discussion}

In this study, we found that the prevalence of vitamin D deficiency was more than $90 \%$, and about $50 \%$ of them had severe deficiency. Interestingly, this public health problem was not changed within the last three years including the year 2020 (with COVID-19 pandemic). Therefore, our female adults have suffered the pandemic with vitamin D deficiency $(>90 \%$ of them), and importantly with severe vitamin D deficiency (about $50 \%)$.

Vitamin D takes an active role in bone homeostasis by affecting the calcium and phosphorus metabolism along with parathormone 
$(1,2)$. However, its effect is not confined to bones and vitamin D has been shown to be associated with cardiovascular, respiratory system, autoimmune, and neurodegenerative diseases and diabetes mellitus (8-14). Vitamin D is severe and insufficient in $50-90 \%$ of the individuals worldwide and their vitamin D levels are below $20 \mathrm{ng} / \mathrm{mL}$ (18).

Vitamin D deficiency is a prevalent and major global health problem which is mostly associated with the lack of sunlight exposure. Vitamin D deficiency can be considered a pandemic in many parts of the world, especially in Europe (19). Sun is the natural source of UV-B, accounting for $1-10 \%$ of UV rays. Sunlight exposure may decrease in a large part of the population due to various reasons such as working indoors, modern and traditional life activities such as indoor time activities, protective sunscreens, and an immobilization due to aging. However, exposing the arms and legs to direct sunlight for 5-30 minutes between 10:00 to 15:00 hours twice a week can produce sufficient vitamin D status (20). Similarly, exposing $24 \%$ of the body surface area (face, arms, and legs) to sunlight for 15 minutes or only $6 \%$ of the body surface area (face and hands)

\section{Table 1. Age-based comparisons for vitamin D status}

\begin{tabular}{|l|l|l|l|l|l|}
\hline \multirow{2}{*}{ Age group (years) } & \multirow{2}{*}{ Total } & \multicolumn{3}{|c|}{ Vitamin D level, ng/mL } & \multirow{2}{*}{$\mathbf{p}^{*}$} \\
\cline { 3 - 6 } & & $<10$ & $10-20$ & $129(41.2 \%)$ & $28(8.9 \%)$ \\
\hline$<30$ & $313(100 \%)$ & $156(49.8 \%)$ & $163(41.7 \%)$ & $38(9.7 \%)$ & 0.760 \\
\hline $30-50$ & $391(100 \%)$ & $190(48.6 \%)$ & $80(37.0 \%)$ & $19(8.8 \%)$ & \\
\hline$>50$ & $216(100 \%)$ & $117(54.2 \%)$ & $372(40.4 \%)$ & $85(9.2 \%)$ & \\
\hline Total & $920(100 \%)$ & $463(50.3 \%)$ & & & \\
\hline${ }^{*}$ Chi-square test & & & & \\
\hline
\end{tabular}

\section{Table 2. Comparisons of vitamin D levels by months $(\mathrm{ng} / \mathrm{mL})$}

\begin{tabular}{|c|c|c|c|}
\hline Month (year) & n (\%) & $\begin{array}{l}\text { Vitamin D level median } \\
\text { (min-max) }\end{array}$ & $p^{\&}$ \\
\hline Total-April & $526(100 \%)$ & - & \\
\hline 2017 & $8315.7 \%)$ & $18.2(3.2-37.2)^{\star}$ & \multirow{4}{*}{$<0.001$} \\
\hline 2018 & 205 (38.9\%) & $8.1(3.0-28.7)$ & \\
\hline 2019 & $199(37.8 \%)$ & $9.6(2.6-33.9)$ & \\
\hline 2020 & $39(7.4 \%)$ & $10.0(5.2-41.8)$ & \\
\hline Total-May & 394 (100\%) & - & \\
\hline 2017 & $88(22.3 \%)$ & $14.0(5.1-31.4)^{*}$ & \multirow{4}{*}{$<0.001$} \\
\hline 2018 & $131(33.2 \%)$ & $10.2(5.0-37.7)$ & \\
\hline 2019 & $131(33.2 \%)$ & $7.9(4.2-30.5)$ & \\
\hline 2020 & $44(11.1 \%)$ & $10.9(4.2-38.2)$ & \\
\hline
\end{tabular}

\section{Table 3. Comparison of vitamin D status by months}

\begin{tabular}{|c|c|c|c|c|}
\hline \multirow{2}{*}{ Month (year) } & \multicolumn{3}{|c|}{ Vitamin D status (ng/mL) } & \multirow{2}{*}{$p^{\&}$} \\
\hline & $<10$ & $10-20$ & $\geq 20$ & \\
\hline \multicolumn{5}{|l|}{ April } \\
\hline $2017^{*}$ & $10(12.0 \%)$ & $33(39.8 \%)$ & $40(48.2 \%)$ & \multirow{4}{*}{$<0.001$} \\
\hline 2018 & $135(65.9 \%)$ & $65(31.7 \%)$ & $5(2.4 \%)$ & \\
\hline 2019 & $106(53.3 \%)$ & $86(43.2 \%)$ & $7(3.5 \%)$ & \\
\hline 2020 & $19(48.7 \%)$ & $15(38.5 \%)$ & $5(12.8 \%)$ & \\
\hline \multicolumn{5}{|l|}{ May } \\
\hline $2017^{*}$ & $23(26.1 \%)$ & $50(56.8 \%)$ & $15(17.0 \%)$ & \multirow{4}{*}{$<0.001$} \\
\hline 2018 & $62(47.3 \%)$ & $65(49.6 \%)$ & $4(3.1 \%)$ & \\
\hline 2019 & $89(67.9 \%)$ & $37(28.2 \%)$ & $5(3.8 \%)$ & \\
\hline 2020 & $19(43.2 \%)$ & $21(47.7 \%)$ & $4(9.1 \%)$ & \\
\hline
\end{tabular}


for 30 minutes can also produce sufficient vitamin D status in the body (21).

Studies have also shown that vitamin $D$ levels change seasonally (22-24). It has also been shown that 25(OH)D levels are lowest in March and highest in September (22). Vitamin $D$ deficiency is highly common in Turkey despite its abundant sunshine. In Adana, vitamin D deficiency was reported in $24.7 \%$ of the population (25). Interestingly, we found that $94.9 \%$ of the individuals had vitamin D deficiency. A study conducted in İmir province, 11.3\% of the subjects had a normal vitamin D levels while $23.2 \%$ of them had deficiency, $46.9 \%$ of them had insufficiency, and $18.6 \%$ of them had a threshold level of deficiency (26). In our study, our female adults had vitamin D deficiency (>90\% of them), and importantly with severe vitamin D deficiency (about $50 \%$ ). In a previous study, the mean serum vitamin D level of the subjects at the end of the winter season was reported as $16.9 \pm 13.1 \mathrm{ng} / \mathrm{mL}(27)$. Similarly, we assessed the vitamin D status in April and May as $11.5 \pm 6.2 \mathrm{ng} / \mathrm{mL}$. Another study assessed the vitamin $D$ levels of the subjects throughout an entire year and found that the vitamin D level measured in summer months was twice higher than that of winter months (28).

In our literature review, we found that the findings of the studies on clothing style and face covering are contradictory. A study conducted in Adana province compared veiled women, who covered their hands and face, and unveiled women, who did not cover their extremities and head, and found that all the subjects had a normal vitamin D level (29). Similarly, another study evaluated patient groups that had a vitamin $D$ level of lower than $20 \mathrm{ng} / \mathrm{mL}$ and found no significant difference between veiled and unveiled patients (30). In the same way, Al-Yatama et al. (31) compared three groups (including a control group who wore Western-style clothing, a group who covered the whole body except for the face and hands, and a group who covered the entire body) and found no significant difference among the groups with regard to vitamin $D$ status. In Turkey, the first COVID-19 case was diagnosed on March 11, 2020 and the first comprehensive nationwide lockdown was initiated in April, 2020. Accordingly, we compared that period with the same months in previous years, considering that the prevalence of vitamin D deficiency could be higher during the lockdown period due to the use of facemasks that cover almost two-thirds of the face. However, we found no difference between the lockdown period and the same months of previous years and it was revealed that $89.2 \%$ of 83 subjects had vitamin D deficiency during the lockdown (April-May, 2020) while $96.4 \%$ of 837 patients had vitamin D deficiency during the same months of last three years. As the vitamin D deficiency is so high, thus the effect of restrictions might not have affected this level, or, the evaluation of the first two months after the restriction may have misled us. If there had been a longer follow-up, our results would possibly be different.

\section{Study Limitations}

Our study was limited in several ways. First, it was a singlecenter, short term, retrospective study and had a small patient population. Second, the study only included female adults aged less than 65 years and had no information as to whether the participants used any vitamin D supplements that were not available in their medical records.

\section{Conclusion}

Our findings indicate that there is a serious and urgent public health problem regarding with vitamin D deficiency (>90\%) in our population; and about $50 \%$ of them has severely deficient. This problem is not different from the lockdown period. Given its rare adverse effects and relatively broad safety, sunbathing, food fortification and prophylactic vitamin-D supplementation might serve as a very appropriate and invaluable therapy for these worldwide problems (i.e. vitamin D deficiency and COVID-19)

\section{Ethics}

Ethics Committee Approval: The study protocol was approved by the local Ethics Committee of Clinical Research of Harran University (decision no: HRU/20.11.14, date: 15.06.2020). The study was conducted in accordance with the principles of the Declaration of Helsinki.

Informed Consent: Retrospective study.

Peer-review: Externally peer-reviewed.

\section{Authorship Contributions}

Concept: S.S., A.Y., Design: S.S., A.Y., Data Collection or Processing: S.S., A.Y., Analysis or Interpretation: S.S., A.Y., Writing: S.S.

Conflict of Interest: No conflict of interest was declared by the authors.

Financial Disclosure: The authors declared that this study has received no financial support.

\section{References}

1. Champe PC, Harvey RA, Ferrier DR. Ulukaya E, çeviri editörü. Lippincott's Illustrated Reviews Serisinden: Biyokimya. 3. baskı Nobel Tip Kitapevleri; 2007.

2. Bringhurst FR, Demay MB, Krane SM, Kronenberg HM. Boneand Mineral Metabolism in Health and Disease. In: Kasper DL, Braunwald E, Fauci AS, Hauser SL, Longo DL, Jameson JL, editors. Harrison's Principles of Internal Medicine. $16^{\text {th }}$ ed. New York: MC Graw-HillCompanies; 2005;2:238-86

3. Fidan F, Alkan BM, Tosun A. Çağın pandemisi D vitamin eksikliği ve yetersizliği. Turk J Osteoporos 2014;:20:71-4.

4. Pilz S, Zittermann A, Trummer C, Schwetz V, Lerchbaum E, Keppel $M$, et al. Vitamin $D$ testing and treatment: a narrative review of current evidence. Endocr Connect 2019;8:R27-R43.

5. Türkiye Endokrinoloji ve Metabolizma Derneği. Osteoporoz ve Metabolik Kemik Hastalıkları Tanı ve Tedavi Kılavuzu. 2018.

6. Holick MF, Binkley NC, Bischoff-Ferrari HA, Gordon CM, Hanley DA, Heaney RP, et al. Evaluation, treatment, and prevention of vitamin D deficiency: an Endocrine Society clinical practice guideline. J Clin Endocrinol Metab 2011;96:1911-30. 
7. Uçar F, Taşlıpınar MY, Soydaş AÖ, Özcan N. Ankara Etlik intisas Eğitim Araştırma Hastanesine Başvuran Hastalarda 25-OH Vitamin D Düzeyleri. Eur J Basic Med Sci 2012;2:12-5.

8. Rizzoli R, Boonen S, Brandi ML, Burlet N, Delmas P, Reginster JY. The role of calcium and vitamin $D$ in the management of osteoporosis. Bone 2008;42:246-9.

9. Holick MF. The vitamin D deficiency pandemic: a forgotten hormone important for health. Public Health Rev 2010;32:267-83.

10. Nair R, Maseeh A. Vitamin D: The "sunshine" vitamin. J Pharmacol Pharmacother 2012;3:118-26.

11. Vacek JL, Vanga SR, Good M, Lai SM, Lakkireddy D, Howard PA. Vitamin D deficiency and supplementation and relation to cardiovascular health. Am J Cardiol 2012;109:359-63.

12. Kriegel MA, Manson JE, Costenbader KH. Does vitamin D affect risk of developing autoimmune disease?: a systematic review. Semin Arthritis Rheum 2011;40:512-31.e8.

13. Eyles DW, Burne TH, McGrath JJ. Vitamin D, effects on brain development, adult brain function and the links between low levels of vitamin $D$ and neuropsychiatric disease. Front Neuroendocrinol 2013;34:47-64.

14. Charan J, Goyal JP, Saxena D, Yadav P. Vitamin D for prevention of respiratory tract infections: A systematic review and meta-analysis. J Pharmacol Pharmacother 2012;3:300-3.

15. World Health Organization (2020) Coronavirus disease (COVID-2019) situation reports. Geneva: World Health Organization. https://www.who.int/emergencies/diseases/novelcoronavirus-2019/situation-reports/ (accessed May 2020).

16. Burtiz Ca, Ashwood E.R, Bruns DE. Tietz textbook of clinical chemistry and molecular diagnostics-e-book. Elsevier health sciences 2012.

17. Gonel A, Yetisgin A. False Negative D Vitamin Measurement in LCMS/MS Method Due to Hyperlipidemia: Case Report. Comb Chem High Throughput Screen 2019;22:428-30.

18. Zittermann A, Gummert JF. Nonclassical vitamin D action. Nutrients 2010;2:408-25.

19. Kara M, Ekiz T, Ricci V, Kara Ö, Chang KV, Özçakar L. 'Scientific Strabismus' or two related pandemics: coronavirus disease and vitamin D deficiency. Br J Nutr 2020;124:736-41.

20. Holick MF. Vitamin D deficiency. N Engl J Med 2007;357:266-81.
21. Bogh MK, Schmedes AV, Philipsen PA, Thieden E, Wulf HC. Interdependence between body surface area and ultraviolet $\mathrm{B}$ dose in vitamin $\mathrm{D}$ production: a randomized controlled trial. $\mathrm{Br} \mathrm{J}$ Dermatol 2011;164:163-9.

22. Hansen L, Tjønneland A, Køster B, Brot C, Andersen R, Cohen AS, et al. Vitamin D Status and Seasonal Variation among Danish Children and Adults: A Descriptive Study. Nutrients 2018;10:1801.

23. Niculescu DA, Capatina CAM, Dusceac R, Caragheorgheopol A, Ghemigian A, Poiana C. Seasonal variation of serum vitamin D levels in Romania. Arch Osteoporos 2017;12:113.

24. Eloi M, Horvath DV, Szejnfeld VL, Ortega JC, Rocha DA, Szejnfeld J, et al. Vitamin D deficiency and seasonal variation over the years in São Paulo, Brazil. Osteoporos Int 2016;27:3449-56.

25. Matyar S, Disel NR, Acikalin A, Kutnu M, Inal T. Cukurova Bolgesinde D vitamini düzeyleri. Cukurova Medical Journal 2017;42:320-8.

26. Bozkaya $G$, Ormen M, Bilgili S, Aksit M. D vitamini için güneşten yeterince faydalanıyor muyuz?. Türk Klinik Biyokimya Derg 2017;15:24-9.

27. Hekimsoy Z, Dinç G, Kafesçiler S, Onur E, Güvenç Y, Pala T, et al. Vitamin $D$ status among adults in the Aegean region of Turkey. BMC Public Health 2010;10:782.

28. Ögüş $E$, Surer $H$, Kılınç $A$, Fidancı $V$, Yılmaz $G$, Dindar $N$, et al. D vitamini düzeylerinin aylara, cinsiyete ve yaşa göre değerlendirilmesi. Ankara Med J 2015;15:1-5.

29. Guzel R, Kozanoglu E, Guler-Uysal F, Soyupak S, Sarpel T. Vitamin $D$ status and bone mineral density of veiled and unveiled Turkish women. J Womens Health Gend Based Med 2001;10:765-70.

30. Taşkıran B, Cansu G. Güneydoğu bölgesinde erişkinlerde D vitamini eksikliği/Vitamin D deficiency in adult residents of Southern Turkey. Osmangazi Tıp Dergisi 2017;39:13-20.

31. Al-Yatama Fl, AlOtaibi F, Al-Bader MD, Al-Shoumer KA. The Effect of Clothing on Vitamin D Status, Bone Turnover Markers, and Bone Mineral Density in Young Kuwaiti Females. Int J Endocrinol 2019;2019:6794837. 